\title{
New Plaster Composite with Mineral Wool Fibres from CDW Recycling
}

\author{
Sonia Romaniega Piñeiro, ${ }^{1}$ Mercedes del Río Merino, ${ }^{1}$ and Cristina Pérez García ${ }^{2}$ \\ ${ }^{1}$ School of Building Engineering, Technical University of Madrid, 28040 Madrid, Spain \\ ${ }^{2}$ School of Forestry Engineering and Natural Resources, Technical University of Madrid, 28040 Madrid, Spain \\ Correspondence should be addressed to Sonia Romaniega Piñeiro; s.romaniega@gmail.com
}

Received 23 April 2015; Accepted 25 May 2015

Academic Editor: Robert Cerný

Copyright (c) 2015 Sonia Romaniega Piñeiro et al. This is an open access article distributed under the Creative Commons Attribution License, which permits unrestricted use, distribution, and reproduction in any medium, provided the original work is properly cited.

\begin{abstract}
Over the last decade the intense activity of the building sector has generated large quantities of construction and demolition waste (CDW). In particular, in Europe around 890 million tons of CDW is generated every year; however, only $50 \%$ of them are recycled. In Spain, over the last years 40 millions of tons of construction and demolition waste have been generated. On the other hand, since the implementation of the Technical Building Code regulation the use of mineral wools as building insulation materials has become a widespread solution in both rehabilitation and new construction works, and because of that, this kind of insulation waste is increasing. This research analyzes the potential of a new composite (gypsum and fiber waste) including several mineral wools waste into a plaster matrix. For this purpose, an experimental plan, characterizing the physical and mechanical behaviour as well as the Shore C hardness of the new composite, was elaborated fulfilling UNE Standards.
\end{abstract}

\section{Introduction}

Over the last decade the intense activity of the building sector has generated large quantities of construction and demolition waste $(\mathrm{CDW})$. In particular, in Europe around 890 million tons of CDW is generated every year; however, only $50 \%$ of them are recycled [1]. In 2010 Europe generated about 857 million tonnes of CDW, including hazardous waste and soils, and the estimated mineral wool waste volume in this year was 2.3 million tonnes [2]. Accordingly, $0.2 \%$ of all CDW generated is mineral wool.

Mineral wool is widely used as a building insulation material, representing around $60 \%$ of the total building insulation market [3]. In Europe, the annual production of mineral wool-in volume-between 2003 and 2011, showed an average growth rate of $0.91 \%$. Values in Figure 1 show a great variation in production volumes between years, but the general trend for production volumes is to grow annually.

Due to the importance of this waste, European countries are enforcing national and international policies as well as other measures purposed to minimize the negative effects of waste generation and management on human health and on environment. The purpose of waste policy is also to reduce the use of resources and therefore their resulting environmental impact.

In Spain, over the last years 40 millions of tons of construction and demolition waste have been generated, $72 \%$ is residential works and $28 \%$ in civil engineering works [4]. Therefore, the construction sector and especially in residential construction must assume the aim of reducing the harmful impact that it produces. Consequently it is essential to introduce new measures for CDW prevention or searching for new ways for CDW recycling.

In Spain, the Royal Decree 105/2008 of February 1 is the document that currently regulates the construction and demolition waste at national level, including CDW production and management [5]. This Royal Decree is an essential element of Spanish policies regarding CDW and contributes to the sustainable development of such an important sector for Spanish economy as the construction industry is. 


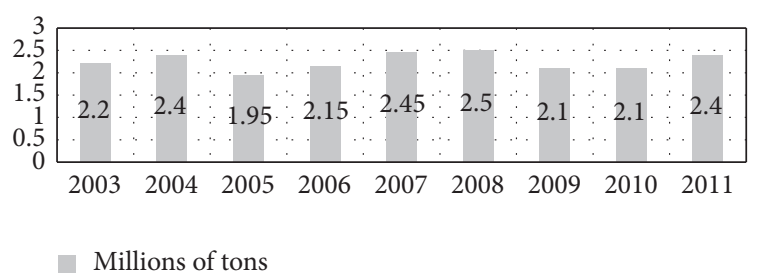

FIGURE 1: Total production of insulating mineral wools in Europe from 2003 to 2011 [2].

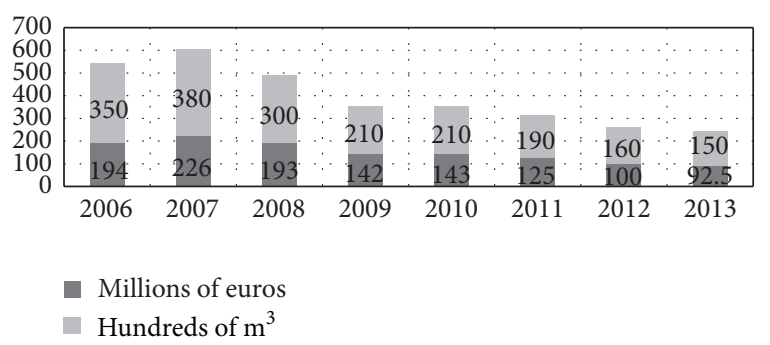

FIgURE 2: Total sales and production of insulating mineral wools in Spain from 2006 to 2013 [6].

Among the main objectives proposed by this Royal Decree, the promotion of reuse and recycling of inert waste from construction and demolition activities can be highlighted.

According to the figures of AFELMA (Spanish Association of Mineral Wool Insulation Manufacturers) website, Figure 2 shows the total sales - in millions of Euros-and the production-in cubic meters-of insulating mineral wools (glass wool and rock wool) from 2006 to 2013 in Spain [6]. The mineral wool waste studied in this research is codified by the European Waste List (EWL) as 1706 04, "Insulating material not containing any asbestos nor hazardous substances," and it is characterized by low levels of reuse, recycling rate, and other ways of recovery. Therefore, the research carried out here studies the feasibility of incorporating CDW mineral wool waste as raw material in plaster matrix in order to reduce its disposal in landfills.

Previous studies focus on reinforcing plaster or gypsum materials by incorporating fibres. In general, results showed an improvement in flexural strength and a decrease in compression strength (Table 1) compared to the values obtained with the plaster without any additive (reference).

Among the natural fibres used for plaster/gypsum reinforcement, the following can be highlighted: short cellulose, sisal, and straw fibres. The behaviour of plaster reinforced with sisal fibres has been discussed by de Oteiza San José and Hernández-Olivares [7, 16]. Moreover, research studies by Klöck and Rahman analyzed the use of paper fibre as reinforcement for gypsum [17, 18]. Gypsum reinforced with straw fibre was studied by Gao or Vardy $[19,20]$.

Many references have been found adding synthetic and mineral fibres to plaster or gypsum matrix-mainly polymer and glass fibres. Ali, $\mathrm{Wu}$, and del Rio Merino studied the mechanical properties of glass fibre $\mathrm{E}$ used for reinforcing gypsum $[8,9,21]$. Santos studied a new gypsum material with EPS beads and short propylene fibres [10], as well as the theoretical model of the mechanical behaviour of plaster and its polymer fibres composite [11]. Moreover, Deng and Furuno also analysed gypsum reinforced with polypropylene fibers [12]. However, none of the fibres used in the above studies came from a recycling process. Therefore, no studies were found reinforcing gypsum composites by adding mineral wool fibres waste.

Furthermore, there are many research studies about the addition of recycled materials, either industrial waste or CDW, in plaster, gypsum, concrete, or mortar. Recycled aggregates are commonly added to concrete, mortar, and asphalt, replacing natural aggregates in road base and subbase layers. Aguilar, Yoda, and Abbas characterised the concrete material elaborated with recycled aggregates from the demolition of concrete structures [22-24]. K.-L. Lin and C.-Y. Lin studied the use of waste sludge ash as raw cement material [25]. Also, other studies focusing on the addition of CDW in plaster matrix are found. Madariaga and Macia studied the addition of expanded polystyrene waste (EPS) gypsum and plaster conglomerates for construction [26]. Moreover, Demirboga and Kan analyzed the addition modified waste expanded polystyrene (MEPS) in concrete [27]. Sabador et al. studied coated paper sludge in a material with pozzolanic properties [28]. del Río Merino investigated gypsum lightened with cork and its application as drywalls for construction [29].

Furthermore, after a thorough revision of literature and scientific articles dealing with gypsum composites, no studies considering mineral wools from CDW were found. Therefore, the main objective of this research is to study the physical and mechanical performance of mineral wools waste added to a plaster matrix and the feasibility of a new composite with less significant environmental impact.

\section{Experimental Plan}

The tests were made in the Construction Materials Laboratory at the School of Building Engineering at the Technical University of Madrid (UPM). The environmental conditions of the laboratory were $23 \pm 2^{\circ} \mathrm{C}$ of average temperature and $50 \pm 5 \%$ of relative air humidity.

2.1. Materials. The materials used were plaster and recycled CDW fibres (mineral wools, rock wool, and glass wool).

The plaster used is classified as E-30-E35 depending on its origin (conglomerate with a plaster base) according to UNE standard 13.279-1 [30] and it is a product certified by $\mathrm{N}$ mark of AENOR. Table 2 shows the main characteristics of plaster E35 Iberyola fast-setting of Placo Company used in this research.

Mineral wool is a flexible material made of inorganic fibres, consisting of interwoven strands of stone materials forming a felt which contains and keeps air motionless. They are obtained through smelting, centrifuging, and other treatments and they are used in construction as thermal and acoustic insulation. Some mineral wools manufacturers include on their labels the detailed environmental information of each product, specifying both the energy needed for 
TABLE 1: Summary of results obtained in previous studies using fibres in plaster/gypsum matrix [7-12].

\begin{tabular}{lccccc}
\hline Author & Kind of fibre & $\begin{array}{c}\text { Length of } \\
\text { fibre }\end{array}$ & $\begin{array}{c}\text { Fibre } \\
\text { addition }\end{array}$ & $\begin{array}{c}\text { Increase in flexural } \\
\text { strength }\end{array}$ & $\begin{array}{c}\text { Decrease in } \\
\text { compression strength }\end{array}$ \\
\hline Santos & Acrylic & $24 \mathrm{~mm}$ & $3 \%$ & $88 \%$ & $23 \%$ \\
Santos & Polyester & $38 \mathrm{~mm}$ & $2 \%$ & $227 \%$ & $50 \%$ \\
Santos & Polypropylene & $20 \mathrm{~mm}$ & $2 \%$ & $59 \%$ & $-6 \%$ \\
Deng and Furuno & Polypropylene & $3 \mathrm{~mm}$ & $9 \%$ & $65 \%$ & - \\
Deng and Furuno & Polypropylene & $12 \mathrm{~mm}$ & $12 \%$ & $20 \%$ & - \\
de Oteiza San José & Sisal & $40 \mathrm{~mm}$ & $2 \%$ & $50 \%$ & $50 \%$ \\
del Río Merino and & Glass E & $25 \mathrm{~mm}$ & $2 \%$ & $250 \%$ & $60 \%$ \\
Comino Almenara & Glass E & $50 \mathrm{~mm}$ & $10 \%$ & & \\
Ali and Grimer & & & & \\
\hline
\end{tabular}

TABLE 2: Technical characteristics of the plaster used in the research [13].

\begin{tabular}{lc}
\hline Purity rate & $>92 \%$ \\
Flexure mechanical strength & $>3.5 \mathrm{~N} / \mathrm{mm}^{2}$ \\
pH scale & $>6$ \\
Granulometry & $0-0.2 \mathrm{~mm}$ \\
Relation W/P & $0.7-0.8 \mathrm{~L} / \mathrm{kg}$ \\
\hline
\end{tabular}

TABLE 3: Environmental information of the glass wool panel used in the research [14].

\begin{tabular}{lccc}
\hline $\begin{array}{l}\text { Thickness } \\
\mathrm{mm}\end{array}$ & $\begin{array}{c}\text { Modules A1-A3 } \\
\text { Primary energy } \\
\mathrm{MJ} / \mathrm{m}^{2}\end{array}$ & $\begin{array}{c}\text { Module A5 } \\
\mathrm{kg} / \mathrm{m}^{2}\end{array}$ & $\begin{array}{c}\text { Waste } \\
\mathrm{kg} / \mathrm{m}^{2}\end{array}$ \\
\hline 50 & 32.60 & 1.44 & 0.210 \\
60 & 37.30 & 1.70 & 0.252 \\
80 & 46.90 & 2.22 & 0.336 \\
\hline
\end{tabular}

its manufacture and the quantity of waste generated. Table 3 shows an example of it.

The difference with other insulations is that this is a fireresistant material, with a melting point higher than $1200^{\circ} \mathrm{C}$. There are two kinds of wools depending on the mineral used as raw material, the glass wool obtained from glass, and the rock wool obtained from basalt rock. Both wools are traded in lots of formats, but mainly through panel or rigid or semirigid sheets.

Due to the fact that rock wool is made from basalt, some manufacturers consider that consequently it is a natural product $100 \%$ recyclable and thus ideal for the development of sustainable building projects [31]. Moreover, mineral wools can also be used for creating new wools. More specifically, we find the following recycling percentage: $66 \%$ of rock wool rejected during the production process and $75 \%$ of glass wool [32]. Recycled glass is also added during the glass wool manufacturing process.

However, as both mineral wools need a large amount of energy for their manufacturing, it seems interesting to look for another purpose, both for the material rejected during the production process and for CDW because this one has not undergone any recycling, reuse, or recovery process.

The mineral wool waste used in this research was generated in a new building under construction located in Madrid (Spain). More specifically, the glass wool waste came from the mineral glass wool panels sold by Ursa Glasswool, in conformity with standard UNE EN 13162 [33], not hydrophilic and coated with kraft paper printed as a vapour barrier. Their potential use is as insulating material for both brickwork and double skin facades. Table 4 shows the main features of Ursa Glasswool used.

On the other hand, the rock wool waste used in this research was generated from the Ursa Terra mineral wool panel. This panel-without coating and supplied in rollsmeets the requirements of UNE EN 13162 standard and it is normally used as insulating material for interior partitions and battered walls. Table 5 shows its main features.

Both glass and rock wools were subjected to the same recycling treatment in order to be incorporated into a plaster matrix; that is, they are crushed, for two minutes, in a $1500 \mathrm{~W}$ power and $50780 \mathrm{~Hz}$ frequency machine (Figure 3).

2.2. Methods. Initially, a study under the microscope is carried out to establish the complete features of the recycled wools. Subsequently, different test samples $4 \times 4 \times 16 \mathrm{~cm}$ were prepared with E35 plaster, recycled rock, and glass wools, following standard UNE-EN 13279-2 [34].

Fourteen series were carried out incorporating previously treated rock wools waste, with a w/p relation of 0.6 and 0.8 and $1 \%$ to $10 \%$ of rock wools waste. Then, eleven series were carried out with treated glass wool waste, with a w/p relation of 0.6 and 0.8 and $1 \%$ to $10 \%$ of glass wool waste. In both cases, when surpassing $10 \%$ of wool waste addition the workability of the mixture became unfeasible. Therefore, additives will be needed if the percentage of wool waste is increased.

Figure 4 shows how both glass and rock wools are distributed homogeneously when incorporated into a plaster matrix.

Shore $\mathrm{C}$ hardness measures were taken according to UNE-EN 102-039-85 [35], and the reference standard for flexural and compressive strength was UNE-EN 13279-2 using the machine model Ibertest. 
TABLE 4: Technical characteristics of the glass wool panel used in the research [14].

\begin{tabular}{|c|c|c|c|c|c|c|c|c|c|}
\hline \multicolumn{3}{|c|}{ Dimensions } & \multirow{2}{*}{$\begin{array}{c}\text { Fire } \\
\text { Fire } \\
\text { EN 13501-1 }\end{array}$} & \multicolumn{2}{|c|}{ Thermal insulation } & \multicolumn{2}{|c|}{ Water vapour behaviour } & \multicolumn{2}{|c|}{ Acoustic behaviour } \\
\hline $\begin{array}{l}\text { Thickness } \\
\text { EN } 823\end{array}$ & $\begin{array}{l}\text { Length } \\
\text { EN } 822\end{array}$ & $\begin{array}{l}\text { Width } \\
\text { EN } 822\end{array}$ & & $\begin{array}{c}\text { Lambda } \\
\text { EN } \\
12667 / 12939\end{array}$ & $\begin{array}{c}\text { Thermal } \\
\text { resistance } \\
\text { EN } \\
12667 / 12939\end{array}$ & $\begin{array}{l}\text { Vapour } \\
\text { diffusion } \\
\text { resistance } \\
\text { EN } 12087\end{array}$ & $\begin{array}{l}\text { Wool vapour } \\
\text { permeability } \\
\text { EN } 12087\end{array}$ & $\begin{array}{l}\text { Air passage } \\
\text { resistance } \\
\text { EN } 29053\end{array}$ & $\begin{array}{c}\text { Air passage } \\
\text { resistance } \\
\text { EN } 29013\end{array}$ \\
\hline $\mathrm{mm}$ & $\mathrm{m}$ & $\mathrm{m}$ & - & $\mathrm{W} / \mathrm{mk}$ & $\mathrm{m}^{2} \mathrm{~K} / \mathrm{W}$ & $\mathrm{m}^{2} \mathrm{hPa} / \mathrm{mg}$ & - & $\mathrm{KPas} / \mathrm{m}^{2}$ & $\mathrm{KPas} / \mathrm{m}$ \\
\hline 50 & 1.35 & 0.60 & $\mathrm{~F}$ & 0.036 & 1.35 & 3 & 1 & 5 & 0.25 \\
\hline 60 & 1.35 & 0.60 & $\mathrm{~F}$ & 0.036 & 1.65 & 3 & 1 & 5 & 0.30 \\
\hline 80 & 1.35 & 0.60 & $\mathrm{~F}$ & 0.036 & 2.20 & 3 & 1 & 5 & 0.40 \\
\hline
\end{tabular}

TABLE 5: Technical characteristics of the rock wool panel used in the research [15].

\begin{tabular}{|c|c|c|c|c|c|c|c|c|c|}
\hline \multicolumn{3}{|c|}{ Dimensions } & Fire & \multicolumn{2}{|c|}{ Thermal insulating } & \multicolumn{2}{|c|}{ Behaviour with water vapour } & \multicolumn{2}{|c|}{ Acoustic behaviour } \\
\hline $\begin{array}{l}\text { Thickness } \\
\text { EN } 823\end{array}$ & $\begin{array}{l}\text { Length } \\
\text { EN } 822\end{array}$ & $\begin{array}{c}\text { Width } \\
\text { EN } 822\end{array}$ & $\begin{array}{c}\text { Fire } \\
\text { EN 13501-1 }\end{array}$ & $\begin{array}{c}\text { Lambda } \\
\text { EN } \\
12667 / 12939\end{array}$ & $\begin{array}{c}\text { Thermal } \\
\text { resistance } \\
\text { EN } \\
12667 / 12939\end{array}$ & $\begin{array}{l}\text { Vapour } \\
\text { diffusion } \\
\text { resistance } \\
\text { EN } 12087\end{array}$ & $\begin{array}{l}\text { Wool vapour } \\
\text { permeability } \\
\text { EN } 12087\end{array}$ & $\begin{array}{l}\text { Air passage } \\
\text { resistance } \\
\text { EN } 29053\end{array}$ & $\begin{array}{l}\text { Air passage } \\
\text { resistance } \\
\text { EN } 29013\end{array}$ \\
\hline $\mathrm{mm}$ & $\mathrm{m}$ & $\mathrm{m}$ & - & $\mathrm{W} / \mathrm{mk}$ & $\mathrm{m}^{2} \mathrm{~K} / \mathrm{W}$ & $\mathrm{m}^{2} \mathrm{hPa} / \mathrm{mg}$ & - & $\mathrm{KPas} / \mathrm{m}^{2}$ & $\mathrm{KPas} / \mathrm{m}$ \\
\hline 45 & 13.5 & 0.40 & $\mathrm{~A} 1$ & 0.036 & 1.25 & - & $<1$ & 5 & 0.22 \\
\hline 45 & 13.6 & 0.60 & $\mathrm{~A} 1$ & 0.036 & 1.25 & - & $<1$ & 5 & 0.22 \\
\hline 65 & 10.8 & 0.40 & $\mathrm{~A} 1$ & 0.036 & 1.80 & - & $<1$ & 5 & 0.32 \\
\hline 65 & 10.8 & 0.60 & $\mathrm{~A} 1$ & 0.036 & 1.80 & - & $<1$ & 5 & 0.32 \\
\hline
\end{tabular}

\section{Results and Discussion}

The average results obtained have been summarized in Table 6 and are further detailed in the following subsections.

3.1. Microscope Analysis. The final mechanical properties do not depend only on the added percentage of fibres but also on the specific bonding between the fibre and the matrix, a contribution which is essential for the material strength. Therefore, a microscope analysis was done in order to determinate the length of the fibres, their composition, and the adherence between the matrix and recycled fibres.

As seen in Figures 5 and 6, both rock wool and glass wool fibres used in this study were less than $0.05 \mathrm{~mm}$ thick and their length vary ranging from $10 \mathrm{~mm}$ to $30 \mathrm{~mm}$.

The microscopic bonding can be analyzed through internal superficial contacts between the matrix and the fibres. In this kind of relations the behaviour can be observed by establishing its extraction force. The greater the force bond and the more compact inside the matrix, the greater the contribution to extraction force. This contribution to the increase of strength is zero if the length of the fibre is encased in a pore. Bonding improves when the fibres show a rough or porous surface.

3.2. Dry Bulk Density. The addition of mineral wool waste to a plaster matrix involves an increase of density in all the cases analyzed in this research (Figure 7). The results show that when adding mineral wool waste (up to $4 \%$ ) in a gypsum matrix, similar density values than those obtained by the reference series are reached (less than 3\% of deviation). This deviation is increased when surpassing $4 \%$ of mineral wool waste addition. This increase is not significant since the biggest difference is around $6.75 \%$ for the sample with $10 \%$ of rock wool (RW) addition and 6\% for the sample with $10 \%$ of glass wool (GW) addition (Table 6).

3.3. Hardness Shore C. The addition of mineral wool waste to a plaster matrix entails an increase of the surface hardness in all the cases (Figure 8). Values of surface hardness Shore $\mathrm{C}$ increase and reach their maximum with $4 \%$ mineral wool sample. With this percentage of waste the results are $14.64 \%$ higher than the reference series for recycled rock wool and $11.23 \%$ for recycled glass wool. From this point on hardness decreases slightly but it always remains above the reference value.

3.4. Flexural Strength. An important increase on strength is observed when increasing the addition of mineral wool waste (Figure 9).

The samples containing rock wools waste (up to $3.5 \%$ ) maintain the flexural strength values similar to the reference, changing less than $5 \%$. If rock wools waste is added in $4 \%$ or more, flexural strength increases continuously reaching a difference of $26.58 \%$ when compared to the reference sample results. This situation is achieved with $10 \%$ of rock wools waste addition.

For the samples that contain glass wool waste, flexure tensile strength decreases as waste percentage increases, 

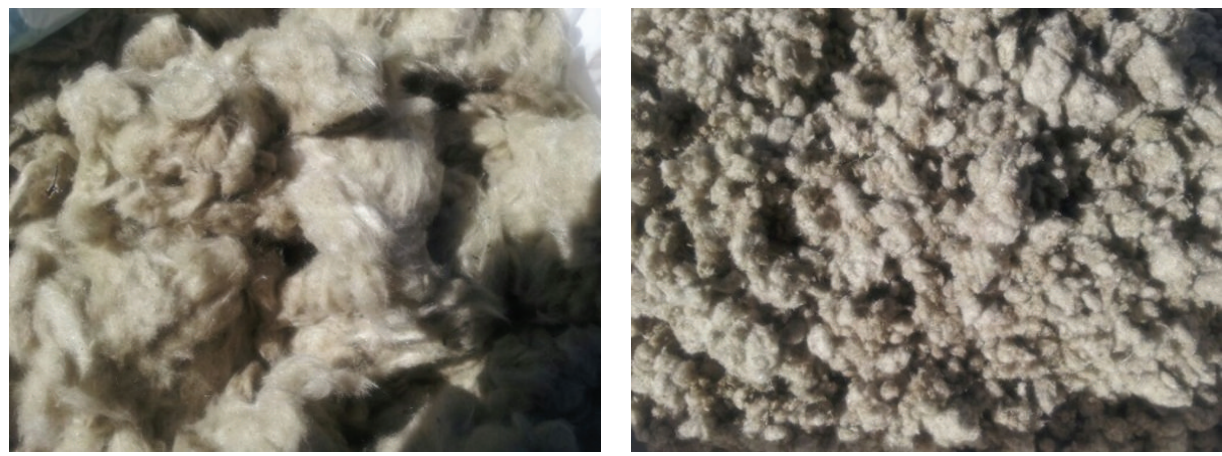

FIGURE 3: Rock wool recycling before and after being processed.

TABLE 6: Tests of average results.

\begin{tabular}{|c|c|c|c|c|c|c|}
\hline & $\begin{array}{l}\% \text { waste } \\
\text { addition }\end{array}$ & $\mathrm{w} / \mathrm{p}$ & $\begin{array}{l}\text { Bulk density } \\
\quad\left(\mathrm{g} / \mathrm{cm}^{3}\right)\end{array}$ & $\begin{array}{c}\text { Surface } \\
\text { hardness Shore } \\
\text { C }\end{array}$ & $\begin{array}{c}\text { Flexural } \\
\text { strength }(\mathrm{MPa})\end{array}$ & $\begin{array}{l}\text { Compressive } \\
\text { strength }(\mathrm{MPa})\end{array}$ \\
\hline \multirow{2}{*}{ Reference } & $0 \%$ & 0.6 & 1.226 & 89.867 & 7.272 & 17.352 \\
\hline & $0 \%$ & 0.8 & 1.014 & 75.400 & 4.247 & 8.708 \\
\hline \multirow{11}{*}{ Recycled rock wool } & $1 \%$ & 0.6 & 1.232 & 90.967 & 7.990 & 18.512 \\
\hline & $1.5 \%$ & 0.6 & 1.212 & 89.767 & 6.991 & 14.330 \\
\hline & $2 \%$ & 0.6 & 1.243 & 91.333 & 7.383 & 13.237 \\
\hline & $2.5 \%$ & 0.6 & 1.213 & 94.333 & 7.047 & 15.147 \\
\hline & $3 \%$ & 0.8 & 1.019 & 83.333 & 4.106 & 6.975 \\
\hline & $3.5 \%$ & 0.8 & 1.026 & 82.167 & 4.427 & 7.245 \\
\hline & $4 \%$ & 0.8 & 1.025 & 86.433 & 5.050 & 9.027 \\
\hline & $5 \%$ & 0.8 & 1.031 & 84.600 & 5.172 & 7.853 \\
\hline & $6 \%$ & 0.8 & 1.017 & 83.933 & 5.366 & 8.168 \\
\hline & $8 \%$ & 0.8 & 1.018 & 81.067 & 5.134 & 8.562 \\
\hline & $10 \%$ & 0.8 & 1.063 & 82.167 & 5.376 & 7.308 \\
\hline \multirow{11}{*}{ Recycled glass wool } & $1 \%$ & 0.6 & 1.238 & 92.333 & 7.263 & 16.613 \\
\hline & $1.5 \%$ & 0.6 & 1.206 & 90.100 & 6.686 & 12.295 \\
\hline & $2 \%$ & 0.6 & 1.199 & 90.433 & 6.373 & 12.017 \\
\hline & $2.5 \%$ & 0.6 & 1.200 & 90.900 & 6.722 & 11.200 \\
\hline & $3 \%$ & 0.8 & 0.999 & 78.933 & 4.283 & 6.110 \\
\hline & $3.5 \%$ & 0.8 & 1.004 & 81.333 & 4.113 & 6.559 \\
\hline & $4 \%$ & 0.8 & 1.009 & 83.867 & 4.673 & 8.153 \\
\hline & $5 \%$ & 0.8 & 1.011 & 81.567 & 4.599 & 7.315 \\
\hline & $6 \%$ & 0.8 & 1.020 & 81.567 & 4.869 & 7.240 \\
\hline & $8 \%$ & 0.8 & 1.045 & 83.133 & 5.046 & 7.542 \\
\hline & $10 \%$ & 0.8 & 1.056 & 80.800 & 5.707 & 7.522 \\
\hline
\end{tabular}

reducing $12.36 \%$ with $2 \%$ addition in relation to reference values. From this point on, strength increases as addition percentage increases, reaching an increase of $34.38 \%$ in relation to reference values for the series with $10 \%$ glass wool waste addition.

Density and mechanical strength are directly related; the increase of both properties is related to the increase of recycled mineral wools percentage addition. Figure 10 shows that samples with higher density achieved higher flexural strength in series containing glass wool (GW) or rock wool (RW) waste.

3.5. Compressive Strength. The compressive strength of the new composite-with both mineral wools-was lower than the reference sample. Nevertheless, all the results exceeded the minimum value stated by the UNE-EN 13279-1 for construction gypsum composites (6 MPa) (Figure 11). 

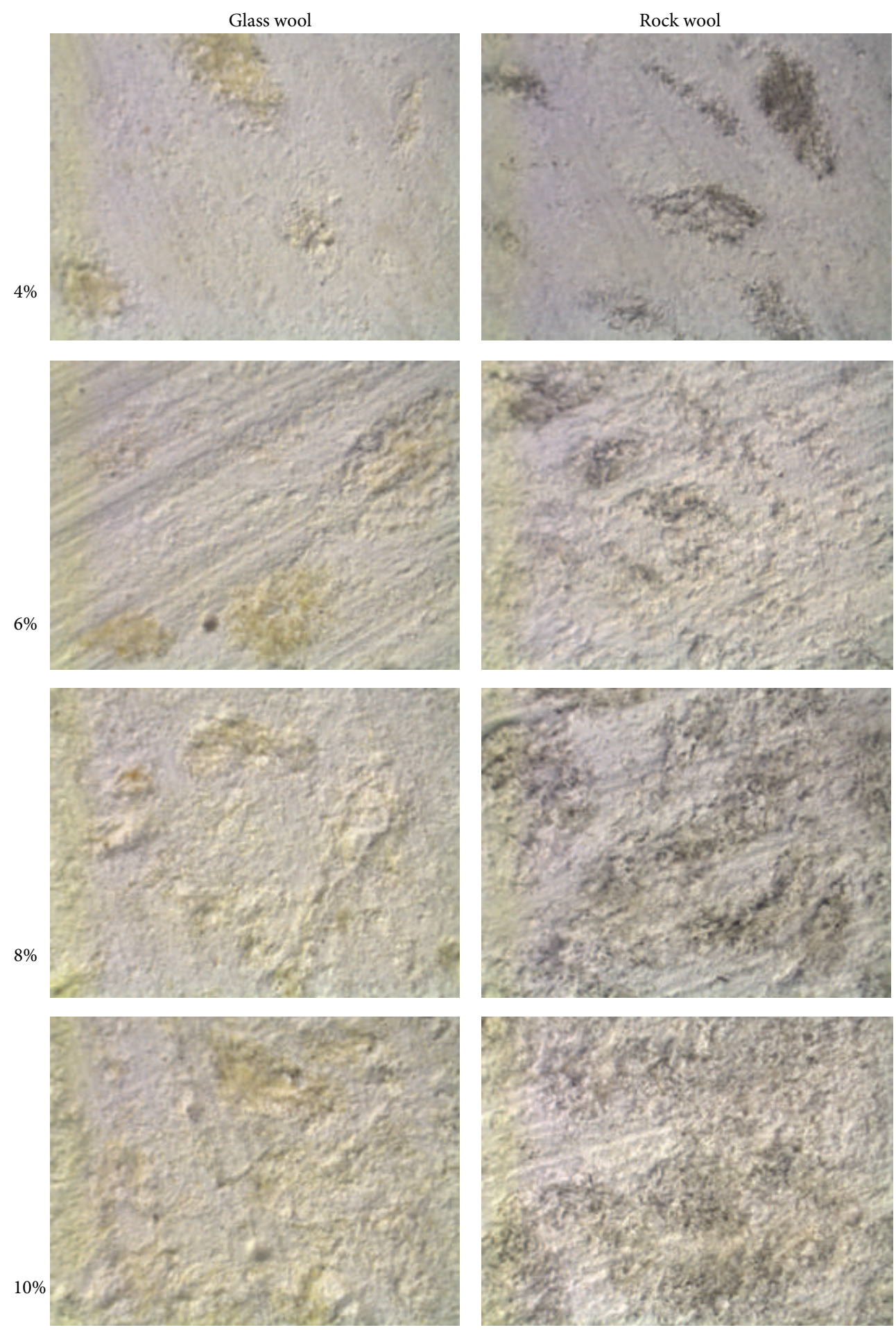

FIGURE 4: Plaster matrix with different glass and rock wool concentrations.

\section{Conclusions}

In this research the physical and mechanical properties of a new composite material reinforced with recycled mineral wools in a plaster matrix have been studied and discussed.
Based on the results of this study the following conclusions can be drawn:

(1) The maximum percentage of mineral wool waste accepted by the mixture, with a w/p proportion of 0.8 


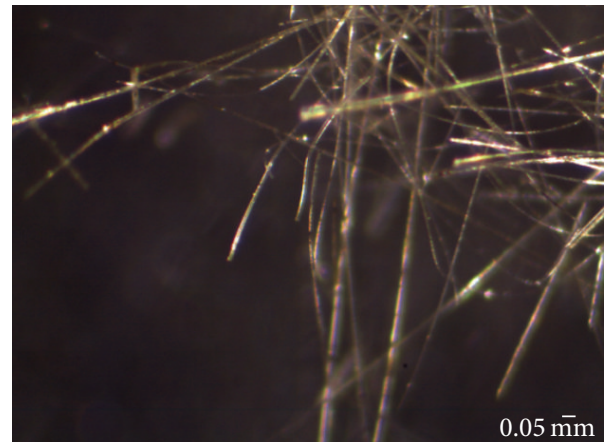

FIGURE 5: Recycled glass wool seen under the microscope with five enlargements.

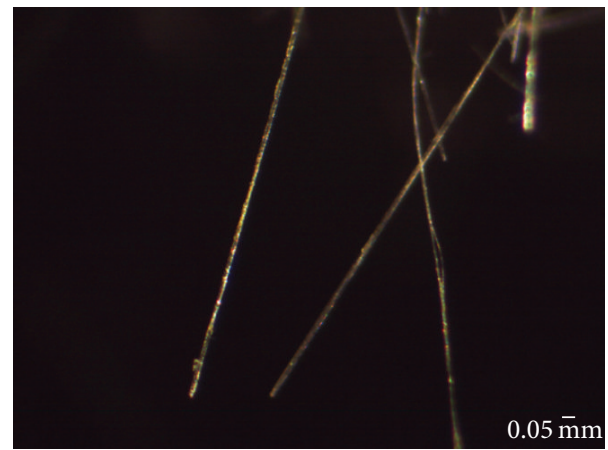

FIGURE 6: Recycled and treated rock wool seen under the microscope with five enlargements.

and 0.6 , is $10 \%$ (in weight), including higher content of mineral wools waste which exceeds the volume of the plaster and thus complicates its workability and increases the amount of air inside the samples.

(2) A good compatibility was found between mineral wool waste used in construction and the plaster matrix. Despite the mineral wools difficulty of absorbing water, these are distributed in a homogeneous way inside the samples, without floating in the mixture.

(3) The plaster composite, with recycled mineral wool waste analysed in this research, increases the density up to $6.75 \%$ compared to the reference samples when using rock wools waste and $6.07 \%$ with glass wool waste.

(4) Surface hardness Shore C values increase gradually till reaching their maximum value with the sample containing $4 \%$ of mineral wools waste. At that level the surface hardness value overcomes more than $10 \%$ of the reference values with both mineral wools.

(5) Flexural strength increases with an increase in recycled mineral wools addition. These values can overcome $34.88 \%$ of the reference samples when adding recycled glass wool and $26.58 \%$ when adding recycled rock wool.

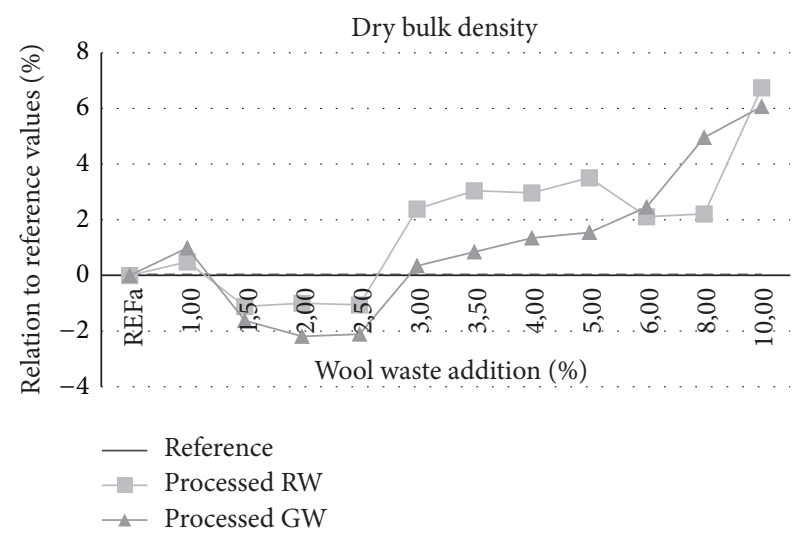

Figure 7: Comparison of the dry bulk density between the series and the reference sample.

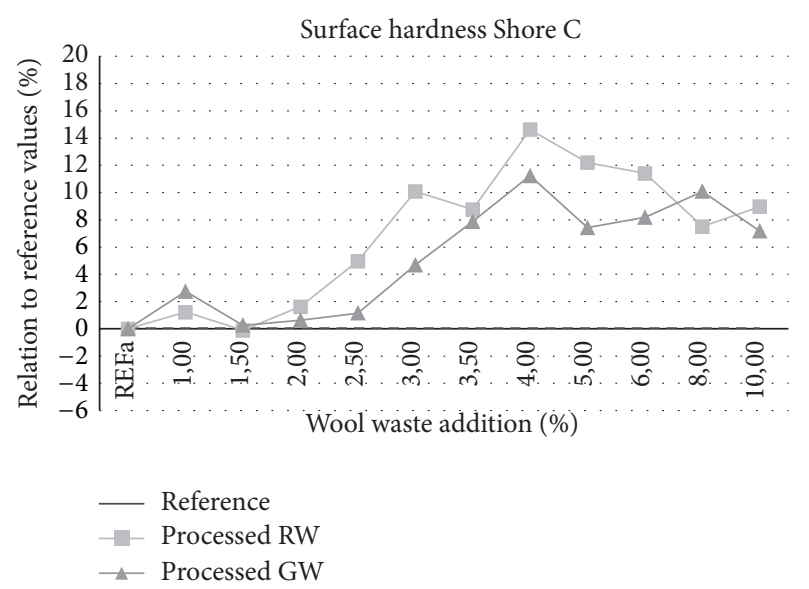

FIgURE 8: Comparison of the surface hardness Shore C between the series and the reference sample.

(6) The compressive strength values obtained with both wools are lower than those obtained with the reference samples. However, the results overcome $6 \mathrm{MPa}$ which is the most restrictive value of compressive strength set by the UNE-EN 13279-1 standard. Thus, according to the tests performed, the proportions of the mixtures, under study so far, could be applied as gypsum or "special gypsum" for construction.

(7) Among the different mineral wools waste studied, glass wool waste is the most suitable to be used as addition for new gypsum composites without decreasing the mechanical behaviour. Flexural strength is increased by more than $30 \%$ compared to the reference series and more than 5\% compared to rock wools waste samples. According to compressive strength, glass wool waste results are lower than those obtained with rock wools waste, and thus the minimum value required by the UNE-EN13279-1 standard is fulfilled.

(8) The flexural strength obtained with recycled mineral wools is slightly higher than the results obtained in 


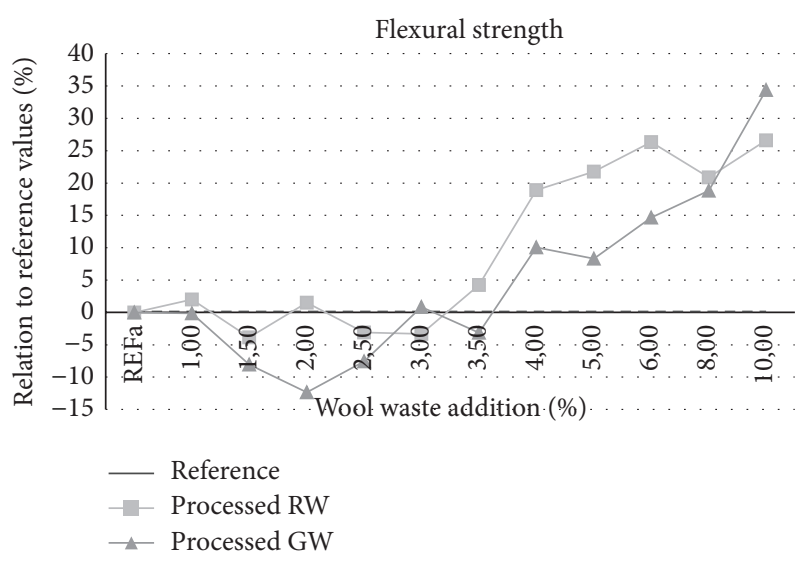

FIGURE 9: Flexural strength comparison between the series and the reference sample.

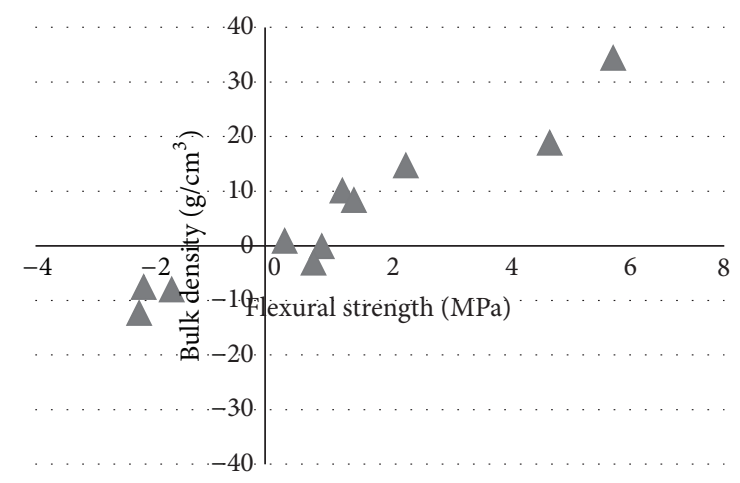

$\Delta$ Processed GW

(a)

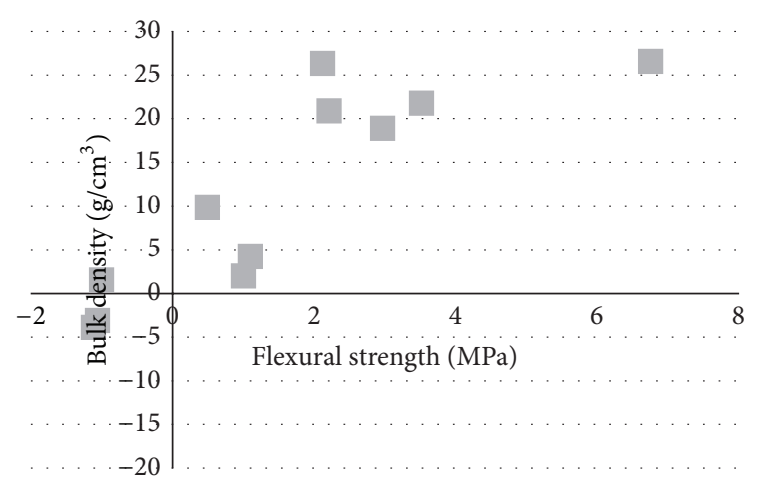

Processed RW

(b)

FIgURE 10: Relation between density and mechanical flexural strength.

previous studies of plaster/gypsum reinforced with fibres, such as sisal short fibres, or even lower when compared to other fibres, such as acrylic, polypropylene, polyester, and glass fibres E. Moreover, compressive strength results obtained with both rock and glass wools waste are higher than the results obtained

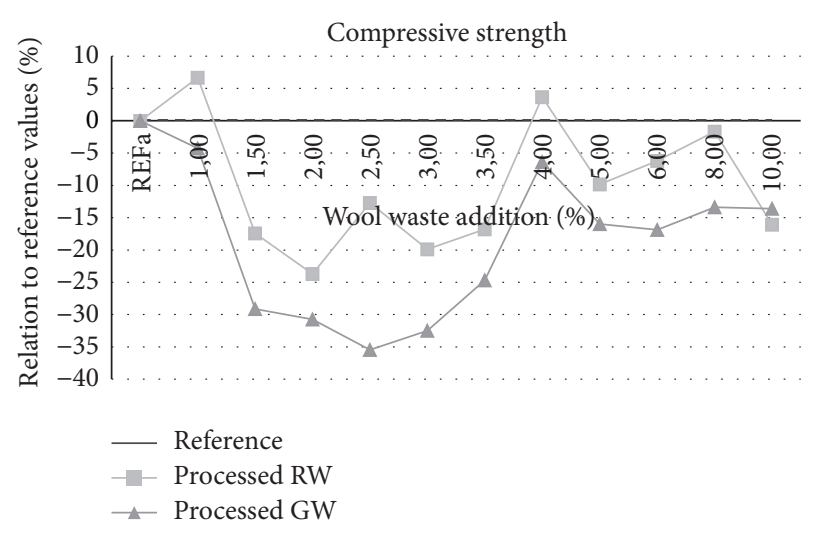

FIGURE 11: Compressive strength comparison between the series and the reference sample.

by other authors with polypropylene, glass E, and polyester fibres. Nevertheless, regarding series with acrylic fibres addition, the results are lower than the ones with recycled rock wool fibres and recycled glass wool fibres with more than $3.5 \%$ addition.

In view of the results, mineral wools waste, both rock wool and glass wool, is suitable for its incorporation into gypsum based products. As an example, it could be embedded in the core of plasterboards increasing their flexural strength. This will help to reduce the huge volumes of waste accumulated in landfills and therefore minimize both social and environmental costs.

\section{Conflict of Interests}

The authors declare that there is no conflict of interests regarding the publication of this paper.

\section{References}

[1] P. Villoria Sáez, M. Del Río Merino, and C. Porras-Amores, "Estimation of construction and demolition waste volume generation in new residential buildings in Spain," Waste Management \& Research, vol. 30, no. 2, pp. 137-146, 2012.

[2] A. M. Papadopoulos, "State of the art in thermal insulation materials and aims for future developments," Energy and Builidings, vol. 37, pp. 77-86, 2005.

[3] O. Väntsi and T. Kärki, "Mineral wool waste in Europe: a review of mineral wool waste quantity, quality, and current recycling methods," Journal of Material Cycles and Waste Management, vol. 16, no. 1, pp. 62-72, 2014.

[4] Ministerio de Medio Ambiente y Medio Rural y Marino, 2008.

[5] Real Decreto 105/2008, de 1 de febrero, por el que se regula la producción y gestión de los residuos de construcción y demolición, 2008.

[6] Afelma, Asociación de fabricantes españoles de lanas minerales aislantes (s.f.), 2015, http://www.aislar.com/.

[7] I. de Oteiza San José, "Study of the behaviour of sisal fiber reinforced hemihydrated gypsum as components in low cost housing," in Informes de la construcción, pp. 425-426, 1993. 
[8] M. A. Ali and F. J. Grimer, "Mechanical properties of glass fibrereinforced gypsum," Journal of Materials Science, vol. 4, no. 5, pp. 389-395, 1969.

[9] M. del Río Merino and P. Comino Almenara, "Análisis de los refuerzos mixtos de fibras de vidrio E y fibras AR en la escayola, como alternativa a los refuerzos monofibras (homogéneos)," Materiales de Construcción, vol. 52, no. 268, pp. 33-42, 2002.

[10] A. G. Santos, "PPF-reenfocad, EPS-lightened gypsum plaster," Materiales de Construcción, vol. 59, no. 293, pp. 105-124, 2009.

[11] A. G. Santos, Modelo teórico del comportamiento mecánico del yeso y sus compuestos fibrosos poliméricos [Ph.D. thesis], 1988.

[12] Y.-H. Deng and T. Furuno, "Properties of gypsum particleboard reinforced with polypropylene fibers," Journal of Wood Science, vol. 47, no. 6, pp. 445-450, 2001.

[13] PLACO, "Placo Saint-Gobain," 2015, http://www.placo.es.

[14] URSA, Technical sheet Panel Mur P1281.

[15] URSA, (s.f.), Technical sheet Ursa Terra-R.

[16] F. Hernández-Olivares, I. Oteiza, and L. de Villanueva, "Experimental analysis of toughness and modulus of rupture increase of sisal short fiber reinforced hemihydrated gypsum," Composite Structures, vol. 22, no. 3, pp. 123-137, 1992.

[17] W. Klöck and S. Aicher, "Size effect in paper fiber-reinforced gypsum panels under in-plane bending," Wood and Fiber Science, vol. 37, no. 3, pp. 403-412, 2005.

[18] T. Rahman, W. Lutz, R. Finn, S. Schmauder, and S. Aicher, "Simulation of the mechanical behavior and damage in components made of strain softening cellulose fiber reinforced gypsum materials," Computational Materials Science, vol. 39, no. 1, pp. 65-74, 2007.

[19] Z. Gao and G. Li, "Effect of straw fiber modification on performance of gypsum composite," Advanced Materials Research, vol. 168-170, pp. 1455-1458, 2011.

[20] S. Vardy and C. MacDougall, "Concentric and eccentric compression experiments of plastered straw bale assemblies," Journal of Structural Engineering, vol. 139, no. 3, pp. 448-461, 2013.

[21] Y.-F. Wu and M. P. Dare, "Flexural and shear strength of composite lintels in glass-fiber-reinforced gypsum wall constructions," Journal of Materials in Civil Engineering, vol. 18, no. 3, pp. 415-423, 2006.

[22] J. C. Aguilar, D. N. Mendoza, R. H. Fuertes, B. B. González, A. T. Gilmore, and R. P. Ramírez, "Caracterización del hormigón elaborado con áridos reciclados producto de la demolición de estructuras de hormigón," Materiales de Construcción, vol. 57, no. 288, pp. 5-15, 2007.

[23] K. Yoda and A. Shintani, "Building application of recycled aggregate concrete for upper-ground structural elements," Construction and Building Materials, vol. 67, pp. 379-385, 2014.

[24] A. Abbas, G. Fathifazl, B. Fournier et al., "Quantification of the residual mortar content in recycled concrete aggregates by image analysis," Materials Characterization, vol. 60, no. 7, pp. 716-728, 2009.

[25] K.-L. Lin and C.-Y. Lin, "Hydration characteristics of waste sludge ash utilized as raw cement material," Cement and Concrete Research, vol. 35, no. 10, pp. 1999-2007, 2005.

[26] F. J. Madariaga and J. L. Macia, "Mezclas de residuos de poliestireno expandido (EPS) conglomerados con yeso o escayola para su uso en la construcción," Informes de la Construcción, vol. 60 , no. 509, pp. 35-43, 2008.

[27] R. Demirboga and A. Kan, "Thermal conductivity and shrinkage properties of modified waste polystyrene aggregate concretes," Construction and Building Materials, vol. 35, pp. 730734, 2012.
[28] E. Sabador, M. Frías, M. I. Rojas, R. Vigil, R. García, and J. T. José, "Caracterización y transformación de un residuo industrial (lodo de papel estucado) en un material con propiedades puzolánicas," Materiales de Construcción, vol. 57, no. 285, pp. 45-59, 2007.

[29] M. del Río Merino, "Yeso aligerado con corcho y su aplicación en paneles para construcción," Patente no. ES2170612A1, OEPM, Madrid, Spain, 2002.

[30] AENOR, "Yesos de construcción y conglomerantes a base de yeso para la construcción. Parte 1: definiciones y especificaciones," UNE-EN 13279-1, AENOR, Madrid, Spain, 2009.

[31] Rockwool firesafe insulation, http://www.rockwool.es.

[32] ISOVER - Saint Gobain, http://www.isover.es.

[33] AENOR, "Productos aislantes térmicos para aplicaciones en la edificación. Productos manufacturados de lana mineral (MW). Especificación," Tech. Rep. UNE-EN 13162, AENOR, Madrid, Spain, 2009.

[34] AENOR, "Yesos de construcción y conglomerantes a base de yeso para la construcción. Parte 2: métodos de ensayo," UNEEN 13279-2, AENOR, Madrid, Spain, 2014.

[35] AENOR, "Yesos y escayolas de construcción. Determinación de la Dureza Shore C, y de la dureza Brinell," Tech. Rep. UNE-EN 102-039-85, AENOR, Madrid, Spain, 1985. 

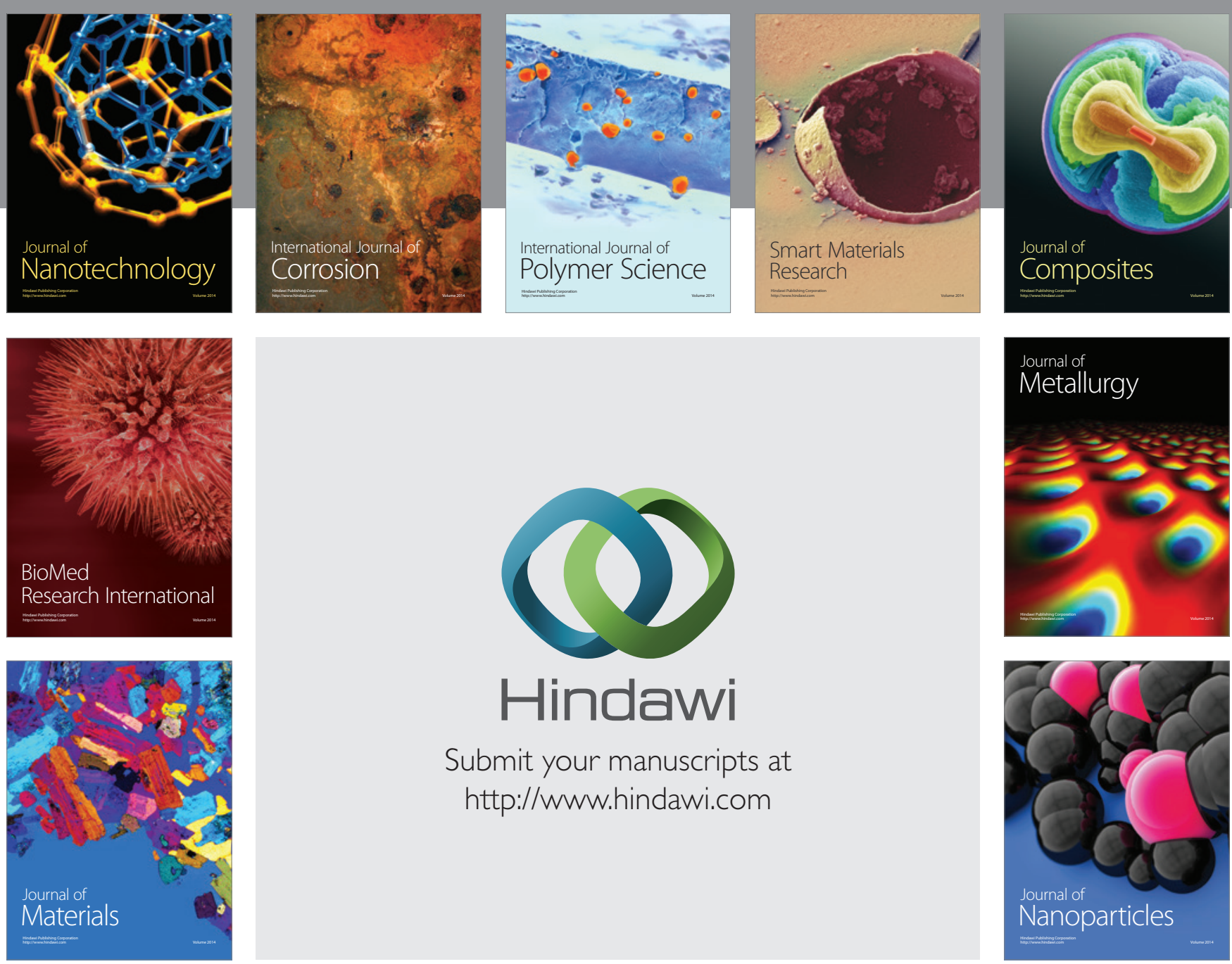

Submit your manuscripts at http://www.hindawi.com
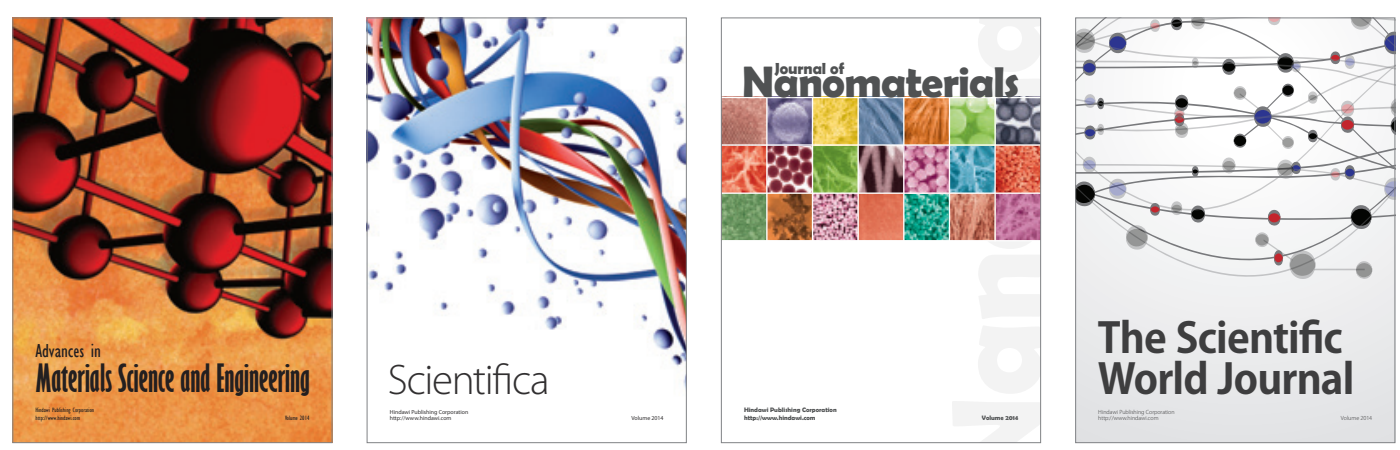

\section{The Scientific World Journal}
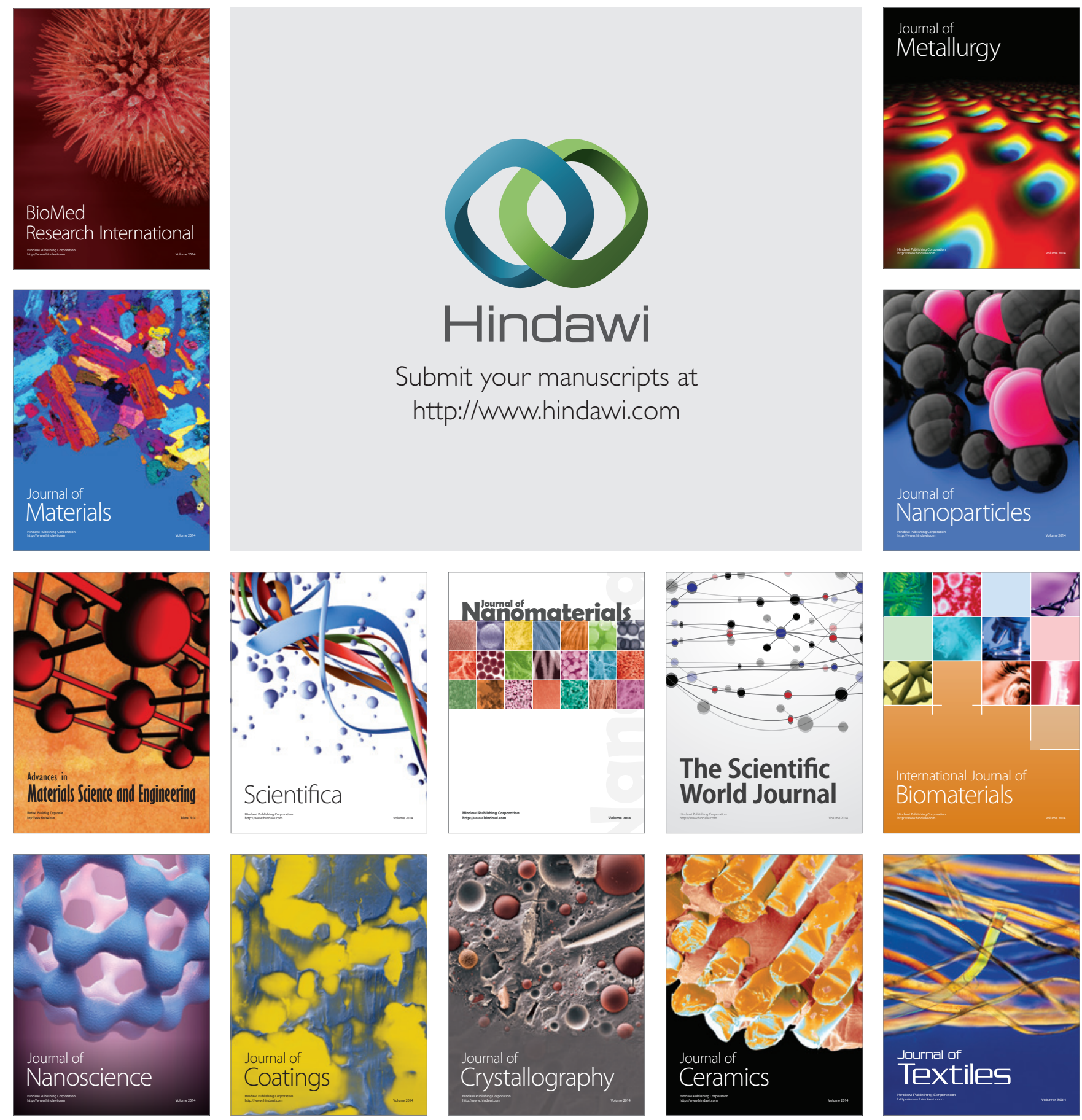